\title{
Expression of Deletion-Containing Dystrophins in $m d x$ Muscle: Implications for Gene Therapy and Dystrophin Function
}

\author{
JEFFERY D. FRITZ, ISTVAN DANKO, STEVEN L. ROBERDS, KEVIN P. CAMPBELL, \\ JEFFREY S. LATENDRESSE, AND JON A. WOLFF
}

Departments of Pediatrics and Medical Genetics, Waisman Center, University of Wisconsin-Madison, Madison, Wisconsin 53705 [J.D.F., I.D., J.S.L., J.A.W.] and Howard Hughes Medical Institute and Department of Physiology and Biophysics, University of Iowa College of Medicine,

lowa City, Iowa 52242 [S.L.R., K.P.C.] \begin{abstract}
ABST
The expression of full-length dystrophin and various dystro-
phin deletion mutants was monitored in $m d x$ mouse muscle after Recombinant dystrophin proteins, including those lacking either the amino terminus, carboxyl terminus, or most of the central rod domain, showed localization to the plasma membrane. This suggests that there are multiple attachment sites for dystrophin to the plasma membrane. Only those constructs containing the carboxyl terminus were able to stabilize dystrophin-associated proteins (DAP) at the membrane, consistent with other studies that suggest that this domain is critical to DAP binding. Colocalization with DAP was not necessary for membrane localization of the various dystrophin molecules. However, stabilization and co-localization of the DAP did seem to be a prerequisite for expression and/or stabilization of mutant dystrophins beyond $1 \mathrm{wk}$ and these same criteria seemed important for mitigating the histopathological consequences of dystrophin deficiency. (Pediatr Res 37: 693-700, 1995)
\end{abstract}

\author{
Abbreviations \\ DMD, Duchenne muscular dystrophy \\ PCR, polymerase chain reaction \\ pRSVDy, plasmid DNA encoding full length dystrophin \\ pRSVDy-B, plasmid DNA encoding Becker-like dystrophin \\ pSV40L, plasmid DNA encoding firefly luciferase \\ pRSVDy-SV40L, plasmid DNA encoding both full-length \\ dystrophin plus luciferase \\ pRSVDy-B-SV40L, plasmid DNA encoding both Becker-like \\ dystrophin plus luciferase \\ pRSVDy-A, plasmid DNA encoding amino-terminal \\ domain-deleted dystrophin \\ pRSVDy-C, plasmid DNA encoding carboxyl-terminal \\ domain-deleted dystrophin \\ pRSVDy-D, plasmid DNA encoding amino- and \\ carboxyl-terminal domain-deleted dystrophin
}

Aberrations in dystrophin expression are responsible for DMD and Becker muscular dystrophy (1). It also appears that deficiencies of dystrophin-associated proteins may play an important role in DMD and other severe childhood myopathies (2). A promising cure for DMD is placement of the normal dystrophin cDNA into affected tissue. Previous transgenic studies in $m d x$ mice - an animal model of DMD (3) — suggest that expression of recombinant dystrophin restores normal muscle morphology and function (4-6). Restoration of dystrophin expression in $m d x$ muscle has also been observed after the injection of retroviral vectors (7), naked plasmid DNA (8),

Received October 30, 1994; accepted February 1, 1995.

Correspondence and reprint requests: Jon A. Wolff, M.D., University of WisconsinMadison, Waisman Center, Room 355, 1500 Highland Avenue, Madison, WI 53705.

Supported by the Muscular Dystrophy Association (U.S.A.).

J.D.F. and S.L.R. were supported by Muscular Dystrophy Association Research Fellowships.

K.P.C. is an Investigator of the Howard Hughes Medical Institute. or adenoviral vectors (9). Dystrophin expression has been shown to improve myofiber survival in $m d x$ muscle after dystrophin gene transfer either by injection of naked plasmid DNA (10) or adenoviral vectors (11).

The main issues concerning DMD gene therapy approaches are: 1) transfer and expression of dystrophin in sufficient numbers of muscle fibers and 2) prevention of disease progression by recombinant dystrophin expression. The transgenic $m d x$ mouse studies imply that recombinant dystrophin expression can correct dystrophic muscle to the extent that it has normal muscle morphology and function (4-6). However, the results obtained with embryonic gene transfer may not extend to somatic gene transfer which would involve gene transfer at later development times. Somatic gene transfer using adenoviral vectors has resulted in stable dystrophin expression only when introduced into neonatal mice (12); a treatment situation difficult to mimic in all DMD patients. Also, limitations on the 
size of the gene to be transferred is currently a problem with adenoviral vectors and has resulted in their use to transfer only a Becker-like dystrophin to dystrophic muscle $(9,11)$. Using adenoviral vectors, it is at present not possible to compare the efficacy between Becker-like and full-length dystrophin expression in dystrophic muscle. Postnatal gene transfer into muscle by intramuscular injection of plasmid DNA has been used to transfer and express genes encoding both the Beckerlike and full-length dystrophins in dystrophic muscle $(8,10)$. Unfortunately, it remains difficult to assess the therapeutic value of this treatment on the muscle as a whole since less than $1 \%$ of the myofibers express dystrophin after intramuscular injection. But this approach does provide sufficient dystrophin expression to assess its therapeutic value at the myofiber level (10).

To further characterize the functional relationships of the various domains of dystrophin, and the importance of these domains in relationship to DMD gene therapy, we examined the expression of various deletion-containing dystrophins in $m d x$ muscle after the intramuscular injection of plasmid DNA. The effect of dystrophin expression on dystrophin-associated protein expression, myofiber survivability, and percentage of centrally located nuclei were used to assess the functionality of the deleted dystrophin domains with regard to dystrophin function or therapeutic value toward DMD gene therapy. Previous studies have shown that the stability of expression of dystrophin in combination with a reporter gene can be used as an indirect indication of myofiber survival $(10,11)$.

\section{METHODS}

Mouse strains. The C57BL/6, Balb/c, and ICR strains were obtained from Harlan Sprague-Dawley (Indianapolis, IN). The $m d x^{4 c v}$ and $m d x^{5 c v}$ strains (gift of V. Chapman) having indistinguishable phenotypes $(13,14)$ were used interchangeably and are simply referred to as $m d x$ mice (10) unless otherwise indicated. These specific strains were used because they have substantially lower number of revertants than the original $m d x$ strain (14).

Plasmid construction, preparation, and injection. Plasmid DNAs pRSVDy, pRSVDy-B, pSV40L.1, pSV40L.2, and pRSVDy-SV40L.1 or pRSVDy-B-SV40L.1, were identical to those previously described (10). The pRSVDy-B construct encodes a dystrophin molecule lacking amino acids 664-2366 (Fig. 1, Becker-like). The pUC19 plasmid was obtained commercially (Life Technologies, Inc., Bethesda, MD).

An expression construct, pRSVDy-A, encoding a dystrophin lacking amino acids 1-277 (Fig. 1, amino terminus) was prepared using PCR primers Dys-Not $\left(5^{\prime}\right.$-GGGCCCGCGGCCGCAATGATCACGGTCAGTCTAGCA-3') and Dys-AatII (5'-CCCGGGCTGACGTCCAGTCTTTATC-3') to amplify the dystrophin cDNA region encoding amino acids 277-1526 from pRSVDy. The Dys-NotI primer has an ATG site located within it so that encoded dystrophin will start with a methionine and then continue with residue 277 . This ensures that this mutant has identical $5^{\prime}$ sequences as the other mutant constructs not containing $5^{\prime}$ deletions. The resulting 3745-bp product was ligated into pCRII (Invitrogen) and the resulting
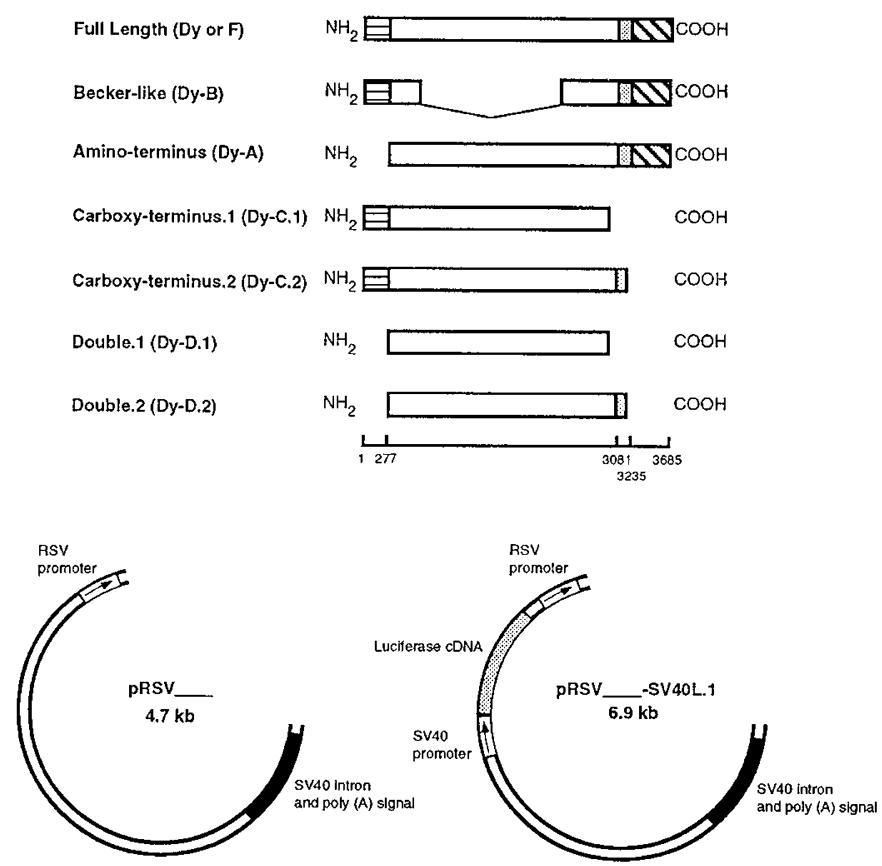

Figure 1. Diagrammatic representation of the dystrophin molecules encoded by the various expression plasmids injected into $m d x$ muscle. The full-length dystrophin sequence and the borders of its varying domains was based on previously published sequence (36). The approximate amino acid boundaries corresponding to the amino-terminal (actin-binding, horizontal shading), spectrin-like repeats (white), cysteine-rich (stippled shading), and carboxylterminal (diagonal shading) domains are noted below the diagram of the double. 2 molecule. The cDNA encoding each of these dystrophin molecules was ligated into either the pRSV or the pRSV-SV40L.1 vectors previously described (10).

plasmid digested with NotI and AatII. This fragment was ligated into pRSVDy (previously digested with NotI and Aat II) to yield pRSVDy-A.

Two carboxyl-terminal dystrophin mutant constructs, pRSVDy-C.1 and pRSVDy-C.2, were also prepared. Construct pRSVDy-C. 1 was prepared by digesting pRSVDy with XhoI and SalI, and then ligating the ends together. The pRSVDyC. 1 construct encodes a dystrophin molecule lacking amino acids 2975-3685 (Fig. 1, carboxyl terminus.1). Construct pRSVDy-C. 2 was prepared by first amplifying a DNA fragment encoding dystrophin amino acids $2829-3195$ by PCR using pRSVDy as template and Dys- NgoMI (5'CCCGGGGCCGGCAGGCACCTATTGG-3') and Dys-SalI (5'-GGGCCCGTCGACC TACTAGACACGGATCCTCCCTGTTCG-3') primers. This PCR fragment was ligated into pCRII and the resulting plasmid digested with $N g o$ MI and Sall. The digested fragment was then cloned into pRSVDy previously digested with $\mathrm{NgoMI}$ and Sall to yield pRSVDy-C.2. The pRSVDy-C. 2 construct encodes a dystrophin molecule lacking amino acids 3196-3685 (Fig. 1, carboxyl terminus.2).

Constructs encoding dystrophin lacking both the amino- and carboxyl-terminal regions were prepared by combining the schemes described above. Construct pRSVDy-D.1 encodes a dystrophin molecule lacking both the amino- and carboxylterminal domains described for both pRSVDy-A and pRSVDyC.1 (Fig. 1, double.1). It was prepared by digesting pRSVDy-A with $X h o I$ and SalI and ligating the resulting ends together. 
Construct pRSVDy-D.2 encodes a dystrophin molecule lacking the regions defined by both pRSVDy-A and pRSVDy-C.2 (Fig. 1, double.2). It was constructed by inserting the $\mathrm{Ngo \textrm {MI } /}$ Sall fragment of pRSVDy-C.2 into pRSVDy-A.

The cDNA sequences encoding these various dystrophin molecules were placed in expression vectors which either lacked or contained a region capable of encoding luciferase (Fig. 1). Vectors containing both luciferase and dystrophin cDNA have the SV40L.1 notation added to the plasmid (i.e. the plasmid encoding both the full-length dystrophin and luciferase was termed pRSVDy-SV40L.1). These vectors serve as indicators of myofiber survival since luciferase expression persists in $m d x$ muscle only after transfer and expression of either full-length or Becker-like dystrophin (10).

All plasmids were purified by alkaline lysis and two $\mathrm{CsCl}$ gradients as previously described (15). Plasmid DNA injections into mouse quadriceps were done in $100 \mu \mathrm{L}$ of normal saline (10). Specific amounts of plasmid DNA injected per quadriceps are given in the figure legends.

Immunohistochemistry, luciferase, and $\beta$-galactosidase assays. Dystrophin immunohistochemistry was performed using antibodies which recognized either the rod (16) (generously provided by L. Kunkel), amino-terminal or carboxyl-terminal domains of dystrophin (17) in combination with biotinconjugated sheep anti-rabbit secondary antibody (Amersham Corp., Arlington Heights, IL) and streptavidin-Texas Red (Life Technologies). The number of dystrophin-positive myofibers per muscle was determined as previously described $(8,10)$. Antibodies specific for $\alpha$-dystroglycan (156-kD dystrophinassociated glycoprotein) (18), $\beta$-dystroglycan (43-kD dystrophin-associated glycoprotein) $(18,19)$, and adhalin $(50-\mathrm{kD}$ dystrophin-associated glycoprotein) (20) were also previously described.

The proportion of dystrophin-positive fibers containing centrally located nuclei was determined as previously described (8). Briefly, $m d x$ muscle sections were processed for dystrophin staining (as previously described) and co-stained with propidium iodide (Sigma, St. Louis, MO) to visualize both dystrophin-positive fibers and nuclei (21).

Determinations of luciferase and $\beta$-galactosidase expression were done using previously described methods $(22,23)$.

The $t$ test was used for statistical analysis.

\section{RESULTS}

Full-length and Becker-like dystrophins. Immunohistochemical staining of normal skeletal muscle with appropriate antibodies reveals dystrophin and dystrophin-associated proteins as a continuous staining along the plasmalemma of every muscle fiber. Except for rare revertant fibers, this staining can not be seen in $m d x$ muscle.

The number of dystrophin-positive myofibers was determined at $1 \mathrm{wk}$ and 2 mo after the intramuscular injection of 400 $\mu \mathrm{g}$ of pRSVDy and pRSVDy-B into $m d x$ mouse muscle. Control muscles were injected with $400 \mu \mathrm{g}$ of the plasmid pUC19 under similar conditions. The number of dystrophinpositive myofibers was corrected for revertant fibers by subtracting the number of dystrophin-positive fibers observed in muscles injected with the control plasmid pUC19 which averaged $4 \pm 1$ and $17 \pm 0.5$ (mean \pm SE) at 1 wk and 2 mo after injection, respectively.

Expression of the full-length and Becker-like dystrophin persisted for at least 2 mo after intramuscular injection of the corresponding expression plasmid (Fig. 2). Dystrophin was visualized by immunohistochemical staining with dystrophin antibodies specific for either the amino-terminal, rod or carboxyl-terminal domain (Fig. 3a-c). Full-length dystrophin localized to the sarcolemmal membrane (Fig. $3 a-c$ ) and the localization of both the full-length and Becker-like dystrophin was similar (data not shown). The number of dystrophinpositive fibers increased slightly from 1 wk to 2 mo after plasmid DNA injection for samples expressing either the fulllength or Becker-like dystrophins (Fig. 2). Concomitant with full-length dystrophin expression was the co-localization of the dystrophin-associated proteins adhalin (Fig. 3d), $\alpha$-dystroglycan and $\beta$-dystroglycan (Fig. $4 b$ and $d$ ). Similar observations were made in $m d x$ muscle expressing Becker-like dystrophin (data not shown).

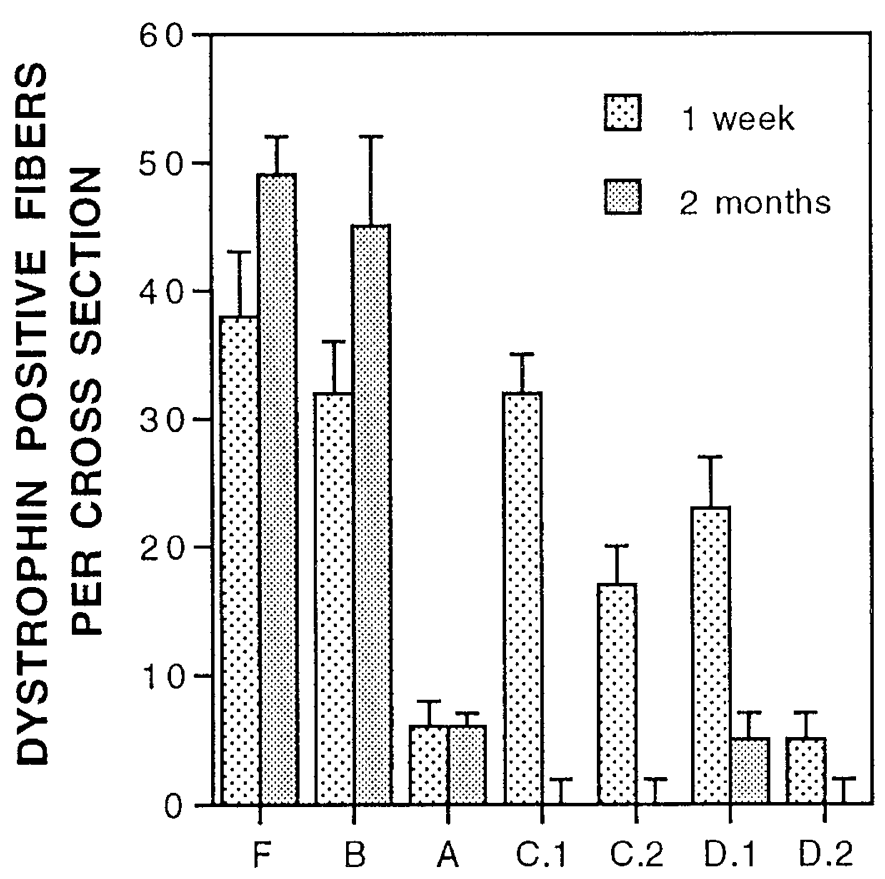

\section{PLASMID INJECTED}

Figure 2. Duration of expression for the various dystrophin molecules in $m d x$ muscle. Mice, 4-6 wks of age, were given intramuscular injections of $400 \mu \mathrm{g}$ of full-length dystrophin expression plasmid pRSVDy $(F), 400 \mu \mathrm{g}$ of Beckerlike expression plasmid pRSVDy-B $(B), 400 \mu \mathrm{g}$ of amino-terminally deleted dystrophin expression plasmid pRSVDy-A $(A), 400 \mu \mathrm{g}$ of carboxyl-terminally deleted dystrophin expression plasmid pRSVDy-C.1 (C.I), $400 \mu \mathrm{g}$ of carboxyl-terminally deleted dystrophin expression plasmid pRSVDy-C.2 (C.2), 400 $\mu \mathrm{g}$ of amino- and carboxyl-terminally deleted dystrophin expression plasmid pRSVDy-D.1 (D.I), or $400 \mu \mathrm{g}$ of amino- and carboxyl-terminally deleted dystrophin expression plasmid pRSVDy-D.2 (D.2). Mice were assayed for dystrophin expression at $1 \mathrm{wk}$ and 2 mo after plasmid injection. At least six different quadriceps muscles (from at least six mice) were examined for each treatment group. Values represent the mean number of dystrophin-positive fibers observed per muscle at the site of plasmid DNA injection, corrected for the number of revertant fibers. Bars indicate SE. 

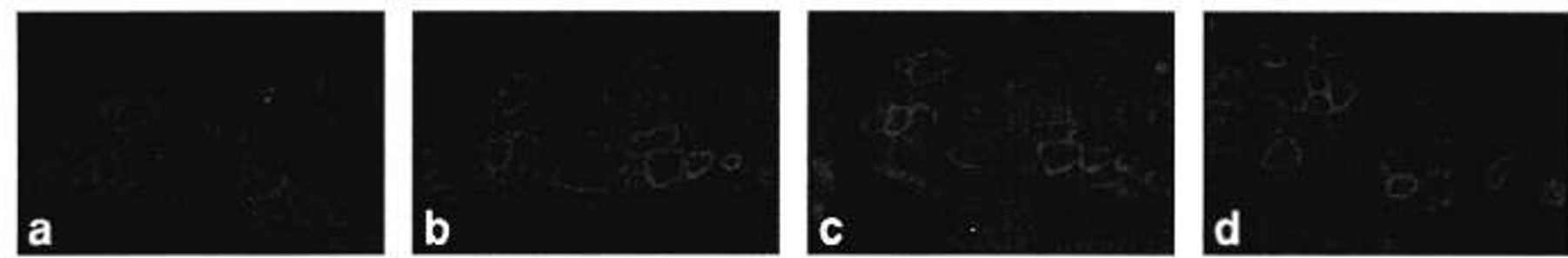

Figure 3. Immunohistochemical detection of dystrophin and adhalin in $m d x$ muscle $1 \mathrm{wk}$ after injection of full-length dystrophin expression plasmid pRSVDy. Serial sections stained with antibodies specific for the amino-terminal $(a)$, spectrin-like repeat $(b)$, and carboxyl-terminal $(c)$ domains of dystrophin and for the dystrophin-associated protein adhalin $(d)$. Magnification, $\times 62.5$.
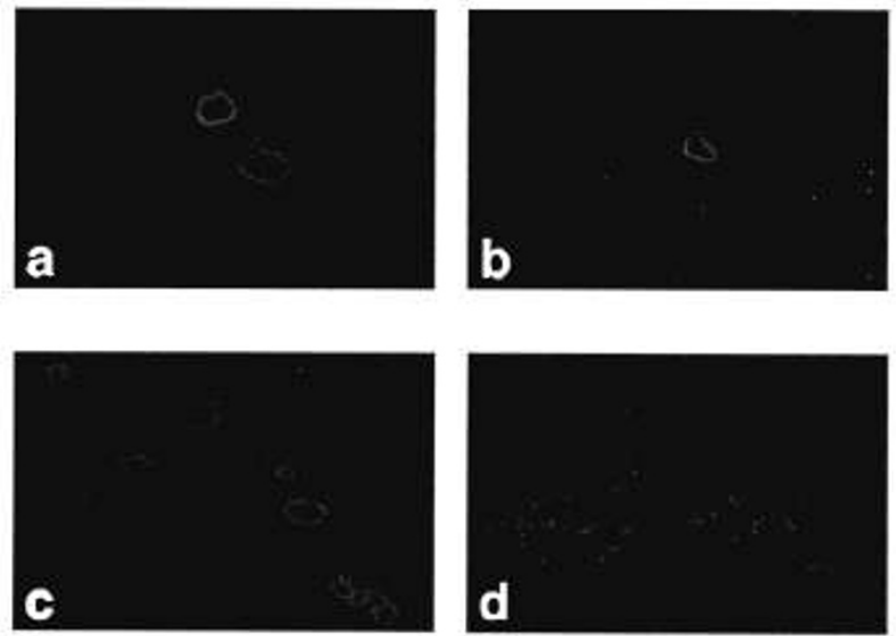

Figure 4. Immunohistochemical colocalization of dystrophin with dystrophin-associated proteins $\alpha$ - and $\beta$-dystroglycan in $m d x$ muscle 1 wk after injection of full-length dystrophin expression plasmid pRSVDy. Two pairs of serial sections $(a, b$, and $c, d)$ are shown. Sections $(a)$ and $(c)$ are stained with antibody specific for the spectrin-like repeat (rod), domain of dystrophin. Sections $(b)$ and $(d)$ were stained with antibodies specific for $\alpha$-or $\beta$-dystroglycan, respectively. Magnifications are $\times 62.5$ for $(a, b)$ and $\times 40$ for $(b, d)$.

The levels of luciferase activity were determined at $1 \mathrm{wk}$ and 2 mo after injection of the plasmid containing both the dystrophin and luciferase genes. Luciferase expression persisted at similar levels between 1 wk and 2 mo after plasmid DNA injection in $m d x$ muscle expressing either full-length or Becker-like dystrophin (Fig. 5). Another indication of improved $m d x$ myofiber health was the significantly decreased number of centrally located nuclei observed in $m d x$ muscle expressing either full-length or Becker-like dystrophin 2 mo after plasmid DNA injection (Fig. 6).

Amino terminus-deleted dystrophin. The number of myofibers expressing a dystrophin which lacked its actin-binding domain was very low at both $1 \mathrm{wk}$ and 2 mo in $m d x$ muscle after intramuscular injection of the respective plasmid (Fig. 2). Using a panel of antibodies specific for different domains of dystrophin, revertant fibers were distinguished from those expressing the amino-terminal domain-deleted dystrophin. Those fibers expressing the amino-terminal domain-deleted dystrophin were visualized with dystrophin antibodies specific for the carboxyl-terminal domain (Fig. $7 b$ ), but were not visualized with the amino-terminal domain specific antibody (Fig. 7a). This dystrophin molecule localized to the sarcolemmal membrane and co-localized with the dystrophin-associated protein $\alpha$-dystroglycan (Fig. 7c). Co-localization with adhalin was also observed during the expression of the amino-terminal domain-

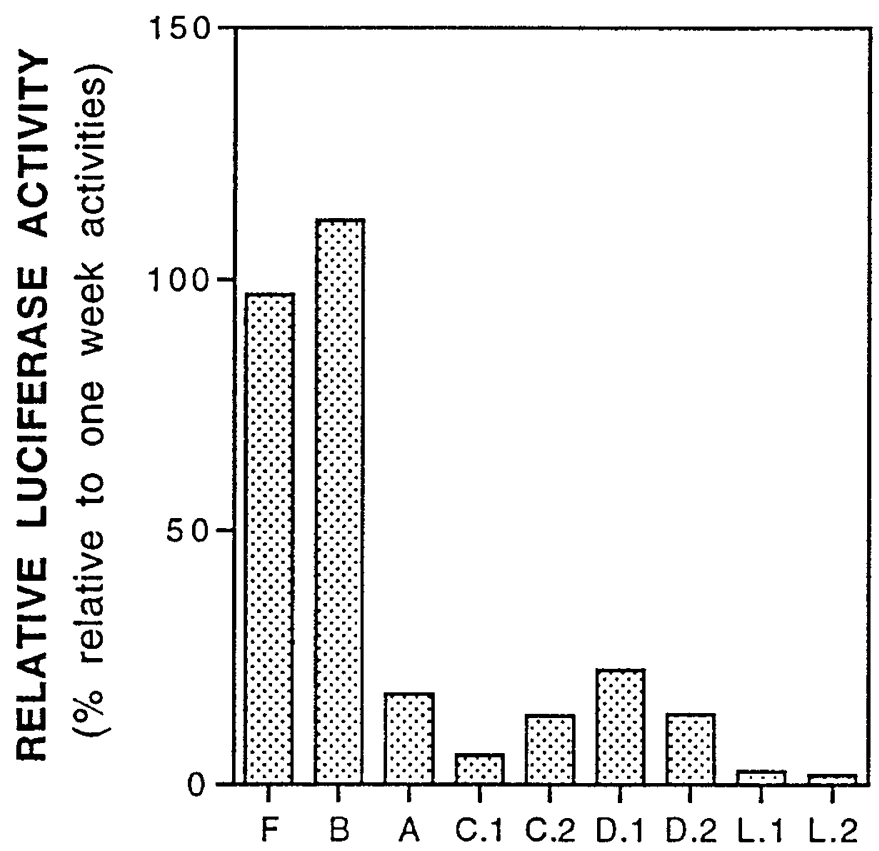

\section{PLASMID INJECTED}

Figure 5. Stability of luciferase expression in $m d x$ mouse muscle. Mice, 4-6 wk of age, were given intramuscular injections of $50 \mu \mathrm{g}$ of pRSVDy-SV40L.1 $(F), 50 \mu \mathrm{g}$ of pRSVDy-B-SV40L.1 $(B), 50 \mu \mathrm{g}$ of pRSVDy-A-SV40L.1 (A), 50 $\mu \mathrm{g}$ of pRSVDy-C.1-SV40L.1 (C.I), $50 \mu \mathrm{g}$ of pRSVDy-C.2-SV40L.1 (C.2), 50 $\mu \mathrm{g}$ of pRSVDy-D.1-SV40L.1 (D.I), $50 \mu \mathrm{g}$ of pRSVDy-D.2-SV40L.1 (D.2), $10 \mu \mathrm{g}$ of pSV40L.1 (L.1), or $10 \mu \mathrm{g}$ of pSV40L.2 (L.2). Mice were assayed for luciferase expression at $1 \mathrm{wk}$ and 2 mo after plasmid injection. At least six different quadriceps muscles (from at least six mice) were examined for each treatment group. Values represent the relative luciferase activity remaining at 2 mo compared with levels observed at $1 \mathrm{wk}$ for each sample.

deleted dystrophin (data not shown). Luciferase expression in $m d x$ muscle expressing the amino-terminal domain-deleted dystrophin did not persist to the same degree as that observed in $m d x$ muscle expressing either the full-length or Becker-like dystrophin (Fig. 5). The percentage of dystrophin-positive fibers containing centrally located nuclei was greater in $m d x$ muscle expressing the amino-terminal domain-deleted dystrophin number than $m d x$ muscle expressing either the full-length or Becker-like dystrophin. But, this percentage was less than that observed in $m d x$ muscle injected with control plasmid, pUC19 (Fig. 6).

Carboxyl terminus-deleted dystrophins. Expression of dystrophins containing carboxyl-terminal domain deletions was observed at $1 \mathrm{wk}$ after intramuscular injection of the corresponding plasmid DNA but did not persist at 2 mo after 


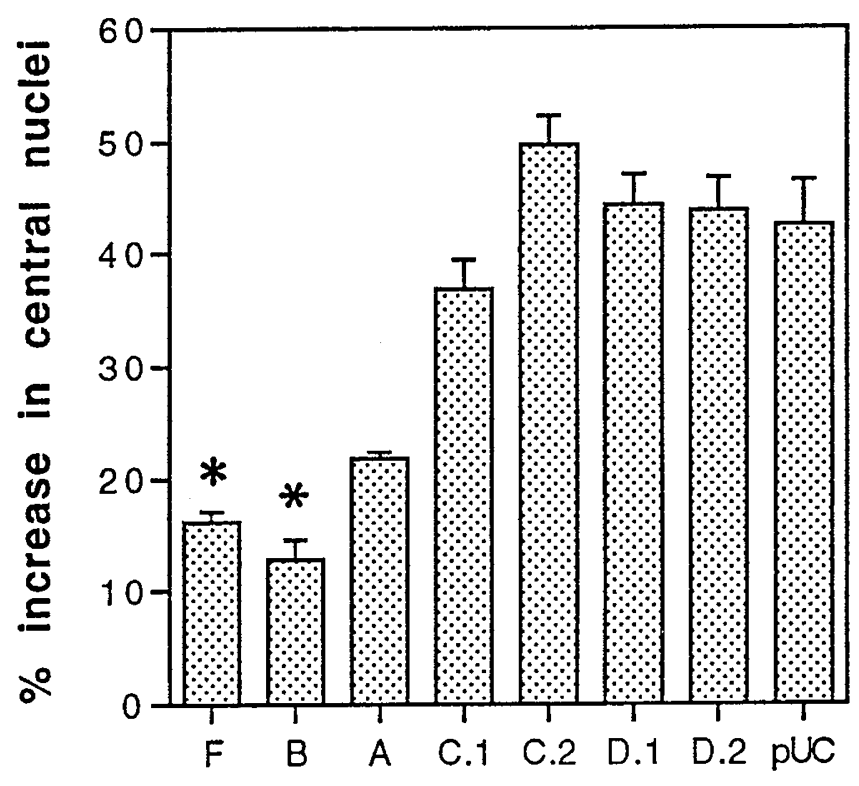

\section{PLASMID INJECTED}

Figure 6. Percentage of dystrophin-positive fibers containing centrally located nuclei 2 mo after intramuscular injection of dystrophin-encoding plasmid DNA into $m d x$ muscle. Mice, 4-6 wk of age, were given intramuscular injections of $400 \mu \mathrm{g}$ of full-length dystrophin expression plasmid pRSVDy $(F), 400 \mu \mathrm{g}$ of Becker-like expression plasmid pRSVDy-B $(B), 400 \mu \mathrm{g}$ of amino-terminally deleted dystrophin expression plasmid pRSVDy-A $(A), 400$ $\mu \mathrm{g}$ of carboxy-terminally deleted dystrophin expression plasmid pRSVDy-C.1 (C.I), $400 \mu \mathrm{g}$ of carboxyl-terminally deleted dystrophin expression plasmid pRSVDy-C.2 (C.2), $400 \mu \mathrm{g}$ of amino- and carboxyl-terminally deleted dystrophin expression plasmid pRSVDy-D.1 (D.I), $400 \mu \mathrm{g}$ of amino- and carboxyl-terminally deleted dystrophin expression plasmid pRSVDy-D.2 (D.2), or $400 \mu \mathrm{g}$ of pUC19 ( $p U C$ ). At least 250 dystrophin-positive fibers observed from at least four different muscles (from at least four mice) were examined for each sample. (*Statistically significant at $p<0.05$.)

injection (Figs. 2 and 8). Using a panel of antibodies specific for either the amino-terminal, rod or carboxyl-terminal domains of dystrophin, it was possible to distinguish revertant fibers from those expressing the carboxyl-terminally deleted dystrophins. Fibers expressing the carboxyl-terminal domaindeleted dystrophin were visualized with the anti-dystrophin antibodies specific for the amino-terminal (Fig. 8a) and rod (Fig. $8 b$ ) domains, but not with the antibodies specific for the carboxyl-terminal domain (Fig. 8c). These truncated dystrophins localized to the sarcolemmal membrane but $\alpha$-dystroglycan sarcolemmal expression was not restored by expression of this construct (Fig. 8d). Sarcolemmal expression of the other dystrophin-associated proteins studied was also not restored (data not shown). Fewer myofibers expressed dystrophin lacking a portion of the cysteine-rich domain and its carboxylterminal domain (Fig. 1, C.1) compared with myofibers expressing either the full-length, Becker-like, or dystrophin with the entire cysteine-rich domain and its carboxyl-terminal domain deleted (Fig. 1, C.2) at $1 \mathrm{wk}$ after plasmid DNA injection (Fig. 2). Luciferase expression did not persist to the same degree in $m d x$ muscle expressing the carboxyl-terminal domain-deleted dystrophin compared with that expressing either the full-length, Becker-like, or actin-binding domain-deleted dystrophins (Fig. 5). Compared to $m d x$ muscle injected with pUC19, muscle injected with the carboxyl-terminally deleted dystrophin constructs had little difference in the number of dystrophin-positive fibers containing centrally located nuclei (Fig. 6).

Amino and carboxyl-terminus-deleted dystrophins. Expression of dystrophins lacking both the amino-terminal domain and the carboxyl-terminal domain was observed only at $1 \mathrm{wk}$ after plasmid DNA injection into $m d x$ muscle (Figs. 2 and 9). At this time, these double-deleted dystrophins localized to the sarcolemma and could be differentiated from revertant fibers on the basis of their reactivity with only the antibody specific for the rod domain of dystrophin (Fig. 9b). No dystrophinassociated proteins were observed in $m d x$ muscle expressing these molecules (Fig. $9 d$ and data not shown). Also, $m d x$ muscle expressing the double-deleted dystrophins did not show persistent luciferase expression (Fig. 5) or decrease in the number of centrally located nuclei observed 2 mo after plasmid DNA injection (Fig. 6).

\section{DISCUSSION}

All the dystrophin constructs studied were expressed at $1 \mathrm{wk}$ after plasmid DNA injection in $m d x$ muscle to different extents (Figs. 2-4 and 7-9). The low level of revertant fibers in the particular strain of $m d x$ mice used in this study (13) and the observation that revertant fibers do not show cytoplasmic
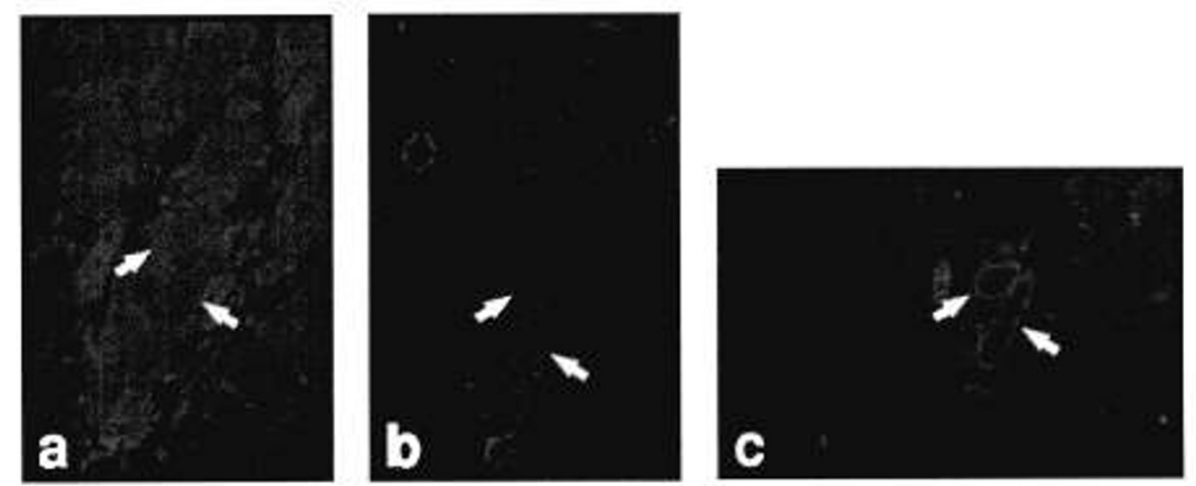

Figure 7. Immunohistochemical detection of dystrophin and $\alpha$-dystroglycan in $m d x$ muscle 1 wk after injection of amino-terminally deleted dystrophin expression plasmid pRSVDy-A. Serial sections stained with antibodies specific for the amino-terminal $(a)$, or carboxyl-terminal $(b)$ domains of dystrophin and antibody specific for $\alpha$-dystroglycan $(c)$. Arrows indicate the presumably transfected fibers expressing amino-terminally deleted dystrophin molecules. Magnification was $\times 40$ except for $(a)$ which was $\times 62.5$. 

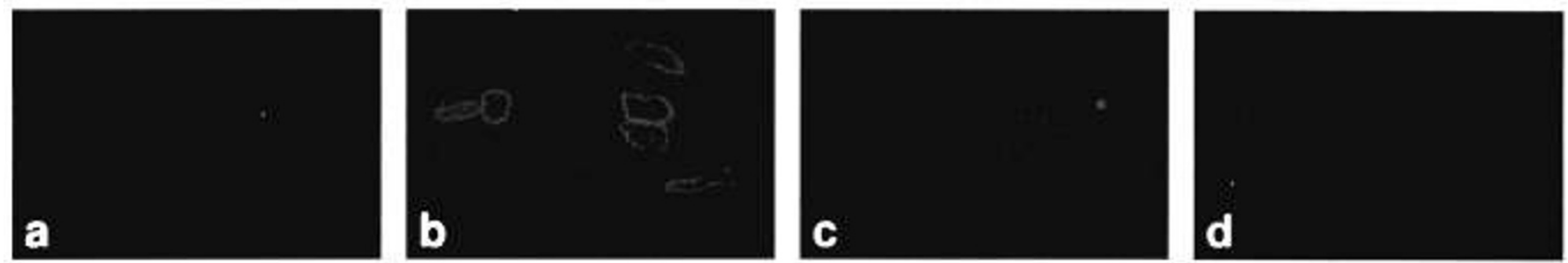

Figure 8. Immunohistochemical detection of dystrophin and $\alpha$-dystroglycan in $m d x$ muscle 1 wk after injection of of carboxyl-terminally deleted dystrophin expression plasmid pRSVDy-C.1. Serial sections stained with antibodies specific for the amino-terminal $(a)$, spectrin-like repeat $(b)$, and carboxyl-terminal $(c)$ domains of dystrophin, and for for $\alpha$-dystroglycan $(d)$. Magnification, $\times 62.5$.
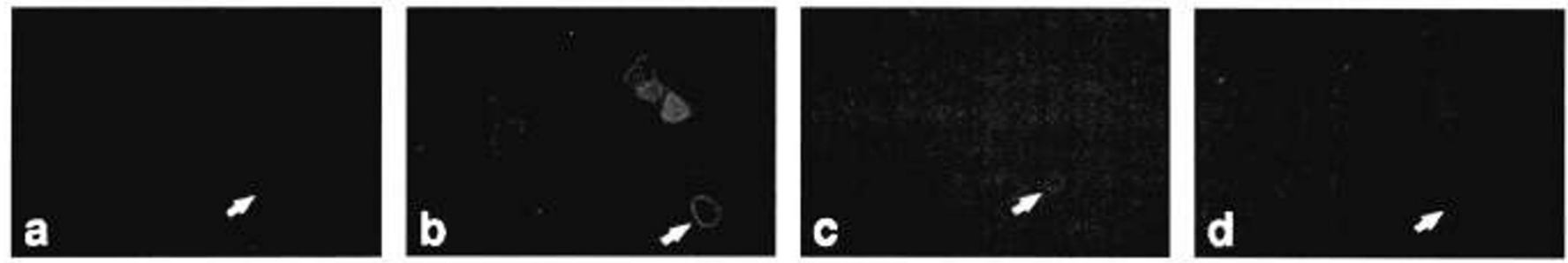

Figure 9. Immunohistochemical detection of dystrophin and adhalin in mdx muscle 1 wk after injection of amino- and carboxyl-terminally deleted dystrophin expression plasmid pRSVDy-D.1. Serial sections stained with antibodies specific for the amino-terminal $(a)$, spectrin-like repeat $(b)$, and carboxyl-terminal $(c)$ domains of dystrophin and for adhalin $(d)$. Arrows indicate a presumed revertant fiber. Magnification, $\times 40$.

dystrophin staining (8) suggested that full-length and Beckerlike dystrophin expression resulted from the cDNA within the injected plasmid DNA. Using a panel of antibodies specific for either the amino-terminal, rod, or carboxyl-terminal domains of dystrophin, it was possible to distinguish revertant fibers from those expressing either the amino- or carboxyl-terminally deleted dystrophins (Figs. 6-9). The differentiation of myofibers expressing the deletion-containing dystrophins from revertants further suggested that dystrophin expression and gene transfer did occur in $m d x$ muscle after intramuscular plasmid DNA injection.

As previously reported (8-11), both the full-length and Becker-like dystrophins were localized at the sarcolemmal membrane (Fig. 3-4). These results were consistent with the sarcolemmal localization of dystrophin in Becker dystrophy patients that express a dystrophin lacking regions of the rod domain $(34,35)$. After injection of the dystrophin genes lacking the amino or carboxyl terminus, the respective dystrophin proteins also were localized to the sarcolemmal membrane (Fig. 7-8). These results were consistent with observations in DMD patients in which dystrophins lacking either the aminoor carboxy terminus were localized to the sarcolemmal membrane (24-33). Similarly, independent localization of dystrophin amino and carboxyl terminus to the cell membrane of $m d x$ muscle cells has recently been reported (45). Both our results and the human studies suggest that neither the amino-terminal nor the carboxyl-terminal domains of dystrophin are completely necessary for trafficking dystrophin to the membrane. These results suggest that there may be multiple regions within the dystrophin molecule responsible for its trafficking to the membrane. It is not unlikely that the portion of the rod domain not deleted from the Becker-like dystrophin also contains sarcolemmal localization cues for dystrophin and may suggest the mechanism by which the double deleted molecules localized to the membrane.
Another important indication of dystrophin function after plasmid injection is its ability to restore expression of the dystrophin-associated proteins. Expression of either the fulllength or Becker-like dystrophins resulted in restoration and co-localization with the dystrophin-associated proteins in individual myofibers. This is in agreement with the expression of dystrophin-associated proteins in transgenic mice expressing full-length dystrophin (4-6). Although low numbers of dystrophin-positive myofibers were observed after the injection of plasmids encoding the amino terminus-deleted dystrophin (Fig. 2), co-localization of dystrophin-associated proteins and amino terminus-deleted dystrophin were observed (Fig. 7). However, no dystrophin-associated proteins co-localized with the fibers expressing the carboxyl-terminally deleted dystrophins (Fig. 8 ). This suggests that the carboxyl-terminal domain of dystrophin was essential for restoration and co-localization with the dystrophin-associated proteins. These results are in agreement with the ability of the carboxyl-terminal domain of dystrophin to complex with dystrophin-associated proteins (37-41).

We have previously shown that stability of dystrophin or luciferase expression can be used as indirect indication of myofiber survival in $m d x$ mouse muscle (10). Expression of the full-length and Becker-like dystrophin persisted for at least 2 mo after intramuscular plasmid DNA injection (Fig. 2). Also in agreement with our previous study (10), co-expression of luciferase with the full-length and Becker-like dystrophin enabled stable expression of luciferase. These results also agree with similar findings using adenovirus-mediated transfer of Becker-like dystrophin $(9,11)$. In contrast, co-expression of luciferase with the amino or carboxy terminus-deleted dystrophins did not enable stable expression of luciferase (Fig. 5). These results are consistent with the Duchenne phenotype observed in patients expressing dystrophins lacking either the amino or carboxyl terminus (24-33). 
It was of interest that expression of the amino terminusdeleted dystrophin was not able to improve myofiber survivability or decrease the number of centrally located nuclei even though it enabled expression of the dystrophin-associated proteins (Figs. 2 and 5-7). This suggests that expression of the dystrophin-associated proteins and their interaction with the carboxyl-terminal domain of dystrophin was not sufficient to correct for the dystrophic phenotype in $m d x$ muscle expressing the amino-terminal domain-deleted dystrophin. However, only those dystrophin constructs that restored dystrophin-associated protein expression resulted in improved myofiber survivability and a decrease in central nuclei. Most likely, myofiber survival requires a network of protein interactions encompassing the amino terminus of dystrophin and cytoplasmic elements such as actin (42), the carboxyl terminus of dystrophin and the dystrophin-associated proteins (37-41), and the dystrophinassociated proteins and extracellular elements such as laminin $(18,43,44)$.

In summary, of the dystrophin molecules studied, only the full-length or Becker-like dystrophins exhibited long-term expression, co-localization with dystrophin-associated proteins, and persistent luciferase expression after plasmid DNA injection into $m d x$ muscle (Figs. 2-5 and 7-9). This suggests that those $m d x$ myofibers expressing either of these dystrophins were less susceptible to myofiber degeneration. Another indication of improved myofiber health was the decreased number of centrally located nuclei observed in $m d x$ muscle expressing either full-length or Becker-like dystrophin (Fig. 6). Restoration of normal muscle morphology and function has been previously observed in transgenic $m d x$ mice expressing dystrophin (4-6). This study suggests that after intramuscular injection of plasmid DNA, $m d x$ myofibers expressing either full-length or Becker-like dystrophin are corrected for dystrophin deficiency and other secondary effects associated with dystrophin deficiency. Thus postnatal gene transfer may be beneficial to DMD patients provided that sufficient numbers of the myofibers express either the full-length or Becker-like DMD gene.

Acknowledgments. The authors thank E. Bostad, S. Hunsaker, and B. True for their technical assistance and J. Ervasti for helpful discussions.

\section{REFERENCES}

1. Hoffman EP, Brown RA, Kunkel LM 1987 Dystrophin: the protein product of the Duchenne muscular dystrophy locus. Cell 51:919-928

2. Matsumura K, Campbell KP 1993 Deficiency of dystrophin-associated proteins: a common mechanism leading to muscle cell necrosis in severe childhood muscular dystrophies. Neuromuscul Disord 3:109-118

3. Bulfield G, Siller WG, Wight PAL, Moore KJ 1984 X chromosome-linked muscular dystrophy $(m d x)$ in the mouse. Proc Natl Acad Sci USA 81:1189-1192

4. Matsumura K, Lee CC, Caskey CT, Campbell KP 1993 Restoration of dystrophinassociated proteins in skeletal muscle of $m d x$ mice transgenic for dystrophin gene. FEBS Lett 320:276-280

5. Lee CC, Pons F, Jones PG, Bies RD, AM Schlang AM, Leger JJ and Caskey CT 1993 $M d x$ transgenic mouse: restoration of recombinant dystrophin to the dystrophic muscle. Hum Gene Ther 4:273-281

6. Cox GA, Cole NM, Matsumura K, Phelps SF, Hauschka SD, Campbell KP, Faulkner JA and Chamberlain JS 1993 Overexpression of dystrophin in transgenic $m d x$ mice eliminates dystrophic symptoms without toxicity. Nature 364:725-729

7. Dunckley MG, Love DR, Davies KE, Walsh FS, Morris GE, Dickson G 1992 Retroviral-mediated transfer of a dystrophin minigene into $m d x$ mouse myoblasts in vitro. FEBS Lett 296:128-134
8. Acsadi G, Dickson G, Love DR, Jani A, Walsh FS, Gurusinghe A, Wolff J and Davies KE 1991 Human dystrophin expression in $m d x$ mice after intramuscular injection of DNA constructs. Nature 352:815-818

9. Ragot T, Vincent N, Chafey P, Vigne E, Gilgenkrantz H, Couton D, Cartaud J, Briand P, Kaplan JC, Perricaudet M 1993 Efficient adenovirus-mediated transfer of a human minidystrophin gene to skeletal muscle of $m d x$ mice. Nature 361 : $647-650$

10. Danko I, Fritz JD, Latendresse JS, Herweijer H, Schultz E, Wolff JA 1993 Dystrophin expression improves myofiber survival in $m d x$ muscle following intramuscular plasmid DNA injection. Hum Mol Genet 2:2055-2061

11. Vincent $\mathrm{N}$, Ragot $\mathrm{T}$, Gilgenkrantz $\mathrm{H}$, Couton $\mathrm{D}$, Chafey $\mathrm{P}$, Gregoire A, Briand $\mathrm{P}$, Kaplan JC, Kahn A and Perricaudet M 1993 Long-term correction of mouse dystrophic degeneration by adenovirus-mediated transfer of a minidystrophin gene. Nat Genet 5:130-134

12. Blau HM 1993 Muscular dystrophy. Muscling in on gene therapy. Nature 364:673-675

13. Chapman VM, Miller DR, Armstrong D, Caskey CT 1989 Recovery of induced mutations for X-chromosome-linked muscular dystrophy in mice. Proc Natl Acad Sci USA 86:1292-1296

14. Danko I, Chapman V, Wolff JA 1992 The frequency of revertants in $m d x$ mouse genetic models for Duchenne muscular dystrophy. Pediatr Res 32:128-131

15. Jiao S, Williams P, Berg RK, Hodgeman BA, Liu L, Repetto G, Wolff JA 1992 Direct gene transfer into nonhuman primate myofibers in vivo. Hum Gene Ther 3:21-33

16. Lidov HGW, Byers TJ, Watkins SC, Kunkel LM 1990 Localisation of dystrophin to postsynaptic regions of central nervous system cortical neurons. Nature 348:725-728

17. Ervasti JM, Kahl SD, Campbel KP 1991 Purification of dystrophin from skeletal muscle. J Biol Chem 266:9161-9165

18. Ibraghimov BO, Ervasti JM, Leveille CJ, Slaughter CA, Sernett SW, Campbell KP 1992 Primary structure of dystrophin-associated glycoproteins linking dystrophin to the extracellular matrix. Nature 355:696-702

19. Ohlendieck K, Campbell KP 1991 Dystrophin-associated proteins are greatly reduced in skeletal muscle from $m d x$ mice. J Cell Biol 115:1685-1694

20. Roberds SL, Anderson RD, Ibraghimov BO, Campbell KP 1993 Primary structure and muscle-specific expression of the $50-\mathrm{kDa}$ dystrophin-associated glycoprotein (adhalin). J Biol Chem 268:23739-23742

21. Viegas PE, Dutrillaux B, Magdelenat H, Coppey MM 1989 Mapping of single-copy DNA sequences on human chromosomes by in situ hybridization with biotinylated probes: enhancement of detection sensitivity by intensified-fluorescence digitalimaging microscopy. Proc Natl Acad Sci USA 86:582-586

22. Wolff JA, Malone RW, Williams P, Chong W, Acsadi G, Jani A, Felgner PL 1990 Direct gene transfer into mouse muscle in vivo. Science 247:1465-1468

23. Wolff JA, Williams P, Acsadi G, Jiao S, Jani A, Chong W 1991 Conditions affecting direct gene transfer into rodent muscle in vivo. BioTechniques 11:474-485

24. Hoffman EP, Garcia CA, Chamberlain JS, Angelini C, Lupski JR, Fenwick R 1991 is the carboxyl-terminus of dystrophin required for membrane association? A novel, severe case of Duchenne muscular dystrophy. Ann Neurol 30:605-610

25. Heliwell TR, Ellis JM, Mountford RC, Appleton RE, Morris GE 1992 A truncated dystrophin lacking the C-terminal domain is localized at the muscle membrane. Am J Hum Genet 50:508--514

26. Roberts RG, Bobrow M, Bentley DR 1992 Point mutations in the dystrophin gene. Proc Natl Acad Sci USA 89:2331-2335

27. Recan D, Chafey P, Leturcq F, Hugnot JP, Vincent N, Tome F, Collin H, Simon D, Czernichow P, Nicholson LV, Fardeau M, Kaplan JC 1992 Are cysteine-rich and $\mathrm{COOH}$-terminal domains of dystrophin critical for sarcolemmal localization? J Clin Invest 89:712-716

28. Bies RD, Caskey CT, Fenwick R 1992 An intact cysteine-rich domain is required for dystrophin function. J Clin Invest 90:666-672

29. Clemens PR, Ward PA, Caskey CT, Bulman DE, Fenwick RG 1992 Premature chain termination mutation causing Duchenne muscular dystrophy. Neurology 42:17751782

30. Sakuraba H, Hori S, Ohtani S, Hanaka S, Abe T, Shimmoto M and Suzuki Y 1993 A case of Duchenne muscular dystrophy with truncated dystrophin. Significance of a cysteine-rich domain for functional expression of dystrophin protein. Brain Dev $15: 222-225$

31. Matsumura K, Tome FM, Ionasescu V, Ervasti JM, Anderson RD, Romero NB, Simon D, Recan D, Kaplan JC, Fardeau M 1993 Deficiency of dystrophin-associated proteins in Duchenne muscular dystrophy patients lacking $\mathrm{COOH}$-terminal domains of dystrophin. J Clin Invest 92:866-871

32. Vainzof M, Takata RI, Passos BM, Pavanello RC, Zatz M 1993 Is the maintenance of the C-terminus domain of dystrophin enough to ensure a milder Becker muscular dystrophy phenotype? Hum Mol Genet 2:39-42

33. Prior TW, Papp AC, Snyder PJ, Burghes AH, Bartolo C, Sedra MS, Western LM, Mendell JR 1993 A missense mutation in the dystrophin gene in a Duchenne muscular dystrophy patient. Nat Genet 4:357-360

34. Morandi L, Mora M, Bernasconi P, Mantegazza R, Gebbia M, Balestrini MR, Cornelio F 1993 Very small dystrophin molecule in a family with a mild form of Becker dystrophy. Neuromuscul Disord 3:65-70

35. Matsumura K, Nonaka I, Tome FM, Arahata K, Collin H, Leturcq F, Recan D, Kaplan JC, Fardeau M, Campbell KP 1993 Mild deficiency of dystrophin-associated proteins in Becker muscular dystrophy patients having in-frame deletions in the rod domain of dystrophin. Am J Hum Genet 53:409-416

36. Koenig M, Monaco AP, Kunkel LM 1988 The complete sequence of dystrophin predicts a rod-shaped cytoskeletal protein. Cell 53:219-228

37. Ervasti JM, Ohlendieck K, Kahl SD, Gaver MG, Campbell KP 1990 Deficiency of a glycoprotein component of the dystrophin complex in dystrophic muscle. Nature 345:315-319 
38. Yoshida M, Ozawa E 1990 Glycoprotein complex anchoring dystrophin to sarcolemma. J Biochem 108:748-752

39. Ohlendieck K, Ervasti JM, Snook JB, Campbell KP 1991 Dystrophin-glycoprotein complex is highly enriched in isolated skeletal muscle sarcolemma. J Cell Biol 112:135-148

40. Suzuki A, Yoshida M, Yamamoto H, and Ozawa E 1992 Glycoprotein-binding site of dystrophin is confined to the cysteine-rich domain and the first half of the carboxyterminal domain. FEBS Lett 30:154-160

41. Kramarcy NR, Vidal A, Froehner SC, Sealock R 1994 Association of utrophin and multiple dystrophin short forms with the mammalian $M_{\mathrm{r}} 58,000$ dystrophin-associated protein (syntrophin). J Biol Chem 269:2870-2876
42. Hemmings I, Kuhlman PA, Critchley DR 1992 Analysis of the actin-binding domain of $\alpha$ actinin by mutagenesis and demonstration that dystrophin contains a functionally homologous domain. J Cell Biol 116:1369-1380

43. Ervasti JM, Campbell KP 1993 A roll for the dystrophin-glycoprotein complex as a transmembrane linker between laminin and actin. J Cell Biol 122:809-823

44. Sunada Y, Bernier SM, Kozak CA, Yamada X, Campbell KP 1994 Deficiency of merosin in dystrophic dy mice and genetic linkage of laminin $M$ chain gene to dy locus. J Biol Chem 269:13729-13732

45. Dunckley MG, Wells KE, Piper TA, Wells DJ, Dickson G 1994 Independent localization of dystrophin $\mathrm{N}$-terminal and $\mathrm{C}$-terminal regions to the sarcolemma of $m d x$ mouse myofibers in-vivo. J Cell Sci 107:1469-1475 